\title{
Aplikasi Proses Anammox Dalam Penyisihan Nitrogen Menggunakan Reaktor Up-Flow Anaerobic Sludge Blanket
}

\section{Application of Anammox Process in Nitrogen Removal Using Up-Flow Anaerobic Sludge Blanket Reactor}

\author{
ZULKARNAINI, RERI AFRIANITA, ILHAM HAGI PUTRA \\ Jurusan Teknik Lingkungan, Universitas Andalas \\ Kampus Limau Manis, Padang - Sumatera Barat, Kode Pos 25163 Telp. 0751-72497 Fax. 0751-72566 \\ Email: zulkarnaini@eng.unand.ac.id
}

\begin{abstract}
Anammox process is a more practical alternative in biological nitrogen removal compared to conventional nitrification-denitrification processes. This process conducted at the optimum temperature of $37^{\circ} \mathrm{C}$. Indonesia, as a tropical country, has the potential for the application of anammox processes to remove nitrogen in wastewater. The purpose of this study was to analyze the efficiency of nitrogen removal in the anammox process using the Up-Flow Anaerobic Sludge Blanket (UASB) reactor at ambient temperature with variations in the hydraulic retention time (HRT) of 24 hours and 12 hours, at the laboratory scale. Samples are measured twice a week using a UV-Vis spectrophotometer. As a seeding sludge for start-up, the reactor was inoculated with granular anammox bacteria genus Candidatus Brocadia. At the stable operation, the ratio of $\Delta N O_{2}{ }^{-}-N: \Delta N H_{4}{ }^{+}-N$ and $\Delta N O_{3}{ }^{-}-N: \Delta N H_{4}{ }^{+}-N$ approach the stoichiometry of the anammox process were 1.20 and 0.21 , respectively. The performance of nitrogen removal with 24-hour HRT obtained a maximum nitrogen removal rate (NRR) of $0.113 \mathrm{~kg}-\mathrm{N} / \mathrm{m}^{3}$.d with nitrogen loading rate (NLR) $0.14 \mathrm{~kg}-\mathrm{N} / \mathrm{m}^{3} . d$, and at 12-hour HRT, maximum NRR of $0.196 \mathrm{~kg}-\mathrm{N} / \mathrm{m}^{3} . d$ with $N L R 0,28 \mathrm{~kg}-\mathrm{N} / \mathrm{m}^{3} . d$. Ammonium Conversion Efficiency (ACE) and Nitrogen Removal Efficiency (NRE) maximum for HRT 24 hours were $82 \%$ and $77 \%$, respectively while HRT 12 hours were $72 \%$ and $68 \%$, respectively. The anammox process operated stably in the tropical temperature with a temperature range of $23-28^{\circ} \mathrm{C}$ on a laboratory scale using the UASB reactor.
\end{abstract}

Keywords: anammox, nitrogen, temperature, tropical, uasb.

\begin{abstract}
ABSTRAK
Proses anammox menjadi alternatif yang lebih efektif dalam penyisihan nitrogen secara biologi dibandingkan dengan proses konvensional nitrifikasi-denitrifikasi. Proses ini berlangsung optimum pada suhu $37^{\circ} \mathrm{C}$. Indonesia sebagai negara tropis memiliki potensi untuk aplikasi proses anammox untuk menghilangkan nitrogen pada air limbah. Penelitian ini bertujuan untuk menganalisis efesiensi penyisihan nitrogen pada proses anammox menggunakan Up-Flow Anaerobic Sludge Blanket (UASB) reaktor pada suhu ambien dengan variasi Waktu Tinggal Hidrolik (WTH) 24 jam dan 12 jam, pada skala laboratorium. Sampel diukur dua kali setiap minggu menggunakan spektrofotometer UV-Vis. Sebagai seeding sludge (lumpur biakan) untuk start-up (memulai) reaktor digunakan bakteri anammox genus Candidatus Brocadia berbentuk granular. Berdasarkan hasil pengukuran, didapatkan nilai rasio $\Delta \mathrm{NO}_{2}{ }^{-}-\mathrm{N}: \Delta \mathrm{NH}_{4}{ }^{+}-\mathrm{N}$ dan $\Delta \mathrm{NO}_{3}{ }^{-}-\mathrm{N}: \Delta \mathrm{NH}_{4}{ }^{+}-\mathrm{N}$ mendekati stoikiometri proses anammox yaitu 1,20 dan 0,21 . Kinerja penyisihan nitrogen dengan WTH 24 jam didapatkan nilai tingkat penyisihan nitrogen (TPyN ) maksimum 0,113 kg$\mathrm{N} / \mathrm{m}^{3}$.h pada tingkat pemuatan nitrogen (TPN) $0,14 \mathrm{~kg}-\mathrm{N} / \mathrm{m}^{3} . \mathrm{h}$, dan WTH 12 jam nilai TPyN maksimum $0,196 \mathrm{~kg}-\mathrm{N} / \mathrm{m}^{3} . \mathrm{h}$ pada TPN $0,28 \mathrm{~kg}-\mathrm{N} / \mathrm{m}^{3}$.h. Nilai efisiensi konversi amonia (EKA) dan efisiensi penyisihan nitrogen (EPN) maksimum pada WTH 24 jam berturut-turut adalah $82 \%$ dan $77 \%$, sedangkan pada WTH 12 jam berturut-turut adalah $72 \%$ dan $68 \%$. Penelitian membuktikan bahwa proses anammox dapat berlangsung stabil pada daerah tropis dengan suhu terukur $21-29^{\circ} \mathrm{C}$ pada skala laboratorium menggunakan UASB reaktor.
\end{abstract}

Kata kunci: Anammox, nitrogen, temperatur, tropis, uasb. 


\section{PENDAHULUAN}

\subsection{Latar Belakang}

Anaerobic amonium oxidation (anammox) adalah proses biologi yang mampu merubah ammonia dalam kondisi anaerobik menjadi gas nitrogen $\left(\mathrm{N}_{2}\right)$ dengan nitrit sebagai penerima electron $^{(1)}$. Penemuan ini pada tahun 1996 menjadi momentum perubahan dalam proses penyisihan nitrogen pada air limbah. Proses anammox terbukti lebih baik dari proses nitrifikasi-denitrifikasi, karena tidak membutuhkan penambahan karbon organik, menghemat kebutuhan oksigen (aerasi) hingga $60 \%$, serta pengurangan produksi lumpur hingga $90 \%$ sehingga mengurangi biaya pengolahan lumpur serta lebih sedikit menghasilkan $\mathrm{N}_{2} \mathrm{O}$ yang merupakan salah satu gas penyebab pemanasan global ${ }^{(2)}$. Proses Anammox telah berhasil diterapkan pada skala laboratorium, skala pilot project dan skala besar untuk pengolahan berbagai jenis air limbah seperti air lindi, air limbah industri, limbah cair farmasi dan jenis limbah lainnya ${ }^{(3)}$. Berdasarkan karakteristik fisiologi bakteri anammox, proses anammox dapat berlangsung pada rentang suhu $20-43{ }^{\circ} \mathrm{C}^{(4)}$. Sedangkan suhu optimal proses anammox adalah $37{ }^{\circ} \mathrm{C}$, akan tetapi telah dilakukan penelitian tentang aplikasi anammox pada suhu dan konsentrasi amonium rendah. Beberapa upaya telah berhasil dilakukan dengan menggunakan air limbah artifisial untuk mengoperasikan proses anammox pada suhu dan konsentrasi amonium yang rendah. Hendrickx et al. (2012) berhasil menggunakan gaslift reactor dengan air limbah artifisial yang mengandung $69 \mathrm{mg}-\mathrm{N} / \mathrm{L} \mathrm{NH}_{4}{ }^{+}-\mathrm{N}$ dan $\mathrm{NO}_{2}{ }^{-}-\mathrm{N}$ sebagai influen pada suhu $20{ }^{\circ} \mathrm{C}^{(5)}$. $\mathrm{Ma}$ et al. (2013) juga menguji kinerja air limbah dengan konsentrasi ammonia rendah, $<20 \mathrm{mg}$ $\mathrm{NH}_{4}{ }^{+}-\mathrm{N}$ pada suhu $16^{\circ} \mathrm{C}$ dan $30^{\circ} \mathrm{C}^{(6)}$. Penyisihan nitrogen yang terjadi selama pengoperasian dapat mencapai lebih dari $90 \%$. Oleh karena itu proses anammox dapat tetap berlangsung dibawah suhu optimum, walaupun mengalami penurunan kinerja penyisihan nitrogen.

Berbagai jenis reaktor sudah digunakan untuk meningkatkan kinerja proses anammox seperti Sequencing Batch Reactor (SBR), Fluidized Bed Reactor (FBR), Upflow Biofilter (UBF), Upflow Anaerobic Sludge Blanket (UASB), Membrane Bioreactor (MBR), Air Lift Reactor (ALR), dan Rotating Biological Contactor $(\mathrm{RBC})^{(7)}$. Tingkat penyisihan tertinggi dicapai dalam UASB dibandingkan dengan SBR dan jenis reaktor lainnya. Pada reaktor anammox skala besar pertama, didapatkan tingkat penghilangan nitrogen hingga $76 \mathrm{~kg}$ $\mathrm{N} / \mathrm{m}^{3}$.hari dan aktivitas anammox spesifik hingga $5,6 \mathrm{~kg}-\mathrm{N} / \mathrm{kg}-\mathrm{VSS} / \mathrm{hari}$. Reaktor UASB lebih efisien dalam mengolah air limbah pada suhu rendah $\left(<30{ }^{\circ} \mathrm{C}\right)$. Konfigurasi proses anammox dipengaruhi oleh tipe penumbuhan bakteri. Tipe penumbuhan bakteri tersebut adalah lumpur granular, lumpur aktif serta biofilm. Lumpur granular memiliki peran penting dalam kinerja bioreaktor tingkat tinggi. Karakteristik lumpur granular berupa granular anammox, granular heterotrofik, granular anaerob, granular denitrifikasi dan granular nitrifikasi autotrofik. Granular anammox dilaporkan memiliki karakteristik warna merah tua (carmine) dengan diameter rata rata 2,2 $2,5 \mathrm{~mm}$. Lumpur granular cocok dikembangbiakkan pada reaktor Air Lift Reactor (ALR), Up-Flow Anaerobic Sludge Blanket (UASB) dan Sequencing Batch Reactor (SBR).

\subsection{Tujuan Penelitian}

Penelitian ini merupakan penelitian dasar dalam mengembangkan dan mengaplikasikan proses anammox untuk penyisihan nitrogen di Indonesia sebagai negara tropis. Sebagai tahapan awal, tujuan penelitian ini adalah untuk melihat kemampuan bakteri anammox menyisihkan nitrogen dengan limbah artifisial berkonsentasi nitrogen rendah pada suhu ambien. Sehingga diharapkan nantinya proses ini dapat diaplikasikan untuk menyisihkan nitrogen pada berbagai jenis air limbah pada skala besar.

\section{BAHAN DAN METODE}

\subsection{Bahan}

Bakteri yang digunakan pada penelitian ini adalah bakteri anammox genus Candidatus Brocadia berbentuk granular dari Kanazawa University, Jepang yang dikultivasi pada suhu $35{ }^{\circ} \mathrm{C}$ (Gambar 1). Sebelum reaktor dioperasikan, bakteri anammox diaklimatisasi pada suhu ruangan menggunakan reaktor kolom selama 3 bulan. Sebagai inokulum, 20 $\mathrm{mL}$ granular bakteri anammox ditambahkan ke dalam reaktor. Komposisi limbah artifisial (per L air kran) yang dialirkan kedalam reaktor terdiri dari $\mathrm{KHCO}_{3}, 500 \mathrm{mg} ; \mathrm{KH}_{2} \mathrm{PO}_{4}, 27,2 \mathrm{mg}$; $\mathrm{MgSO}_{4.7} \mathrm{H}_{2} \mathrm{O}, 300 \mathrm{mg} ; \mathrm{CaCl}_{2.2} \mathrm{H}_{2} \mathrm{O}, 180 \mathrm{mg}$; $\mathrm{CaCl}_{2}, 136 \mathrm{mg}$; larutan trace element I dan II(8) masing-masing $1 \mathrm{~mL} ; \mathrm{NaNO}_{2}$ dan $(\mathrm{NH})_{2} \mathrm{SO}_{4}$ masing-masing $70 \mathrm{mg}-\mathrm{N} / \mathrm{L}$.

\subsection{Metode}

Penelitian menggunakan reaktor UASB dengan volume $300 \mathrm{~mL}$ yang dioperasikan secara kontinu. Substrat dari tangki dialirkan ke dalam reaktor dari bagian bawah menggunakan pompa peristaltik. Tangki substrat disambungkan dengan kantong gas yang berisi nitrogen untuk menjaga kondisi anaerobik dan 
mengatur keseimbangan tekanan atmosfer dalam tangki.

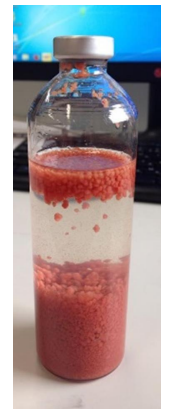

Gambar 1. Bakteri anammox genus Candidatus Brocadia

Pada bagian dasar reaktor dipasang filter untuk mencegah penyumbatan oleh biomasa bakteri. Reaktor ditutupi dengan Aluminium Foil untuk mencegah pertumbuhan bakteri heterotrofik. Skema instalasi reaktor penelitian dapat dilihat pada Gambar 2. Percobaan dilakukan dengan variasi waktu Waktu Tinggal Hidrolik (WTH) 24 jam dan 12 jam seperti terlihat pada Tabel 1. Perubahan WTH dilakukan pada saat efesiensi penyisihan sudah maksimal dan relatif konstan.

Sampel diambil dua kali dalam seminggu pada tangki substrat dan efluen. Konsentrasi amonia dianalisis dengan metode Nessler, nitrit dengan metode spektrofotometri dan nitrat dengan metode reduksi kadmium dan diukur menggunakan spektrofotometer UV-Vis berdasarkan standard method. Suhu dan $\mathrm{pH}$ diukur menggunakan termometer dan $\mathrm{pH}$ meter. Suhu yang diukur adalah suhu ruangan.

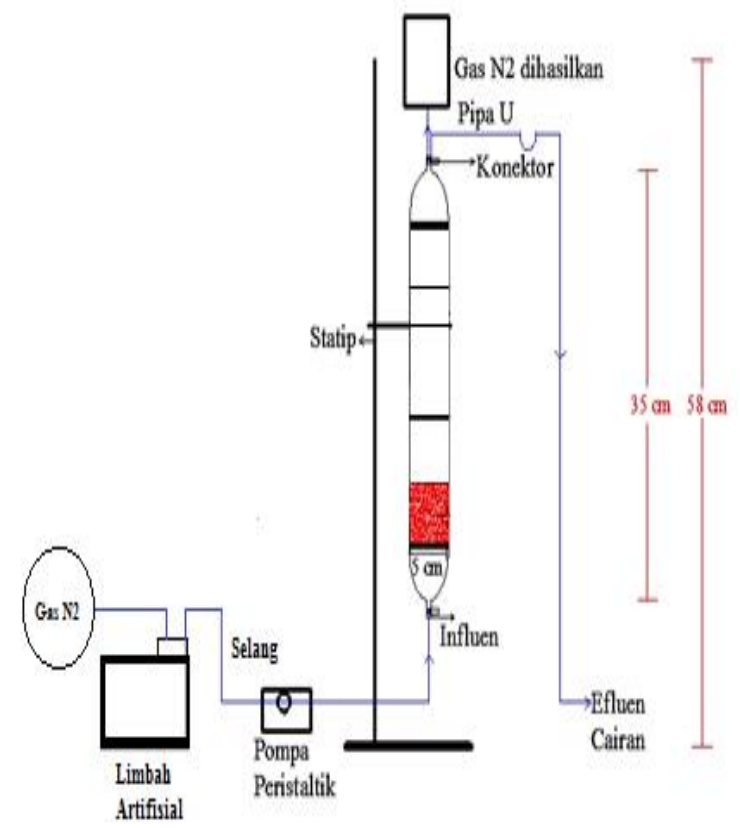

Gambar 2. Skema instalasi reaktor
Perhitungan kinerja reaktor anammox menggunakan persamaan sebagai berikut :

$\operatorname{EKA~}(\%)=\frac{\left[\mathrm{NH}_{4}^{+}-\mathrm{N}\right]_{\text {in }}-\left[\mathrm{NH}_{4}^{+}-\mathrm{N}\right]_{\mathrm{ef}}}{\left[\mathrm{NH}_{4}^{+}-\mathrm{N}\right]_{\text {in }}} \times 100 \% \ldots \ldots \ldots \ldots \ldots \ldots . . . \ldots \ldots$
$\operatorname{EPN~}(\%)=\frac{\left.\left[\mathrm{NH}_{4}^{+}-\mathrm{N}\right]_{\text {in }}+\left[\mathrm{NO}_{2}^{-}-\mathrm{N}\right]_{\text {in }}^{-}\left[\mathrm{NH}_{4}^{+}-\mathrm{N}\right]_{\mathrm{ef}}-\left[\mathrm{NO}_{2}^{-}-\mathrm{N}\right]_{\mathrm{ef}}-\left[\mathrm{NO}_{3}^{-}-\mathrm{N}\right]\right)_{\mathrm{ef}}}{\left[\mathrm{NH}_{4}^{+}-\mathrm{N}\right]_{\text {in }}} \times 100 \%$

TPyN $\left(\mathrm{kg}-\mathrm{N} / \mathrm{m}^{3} \cdot \mathrm{h}\right)=\frac{\left.\left[\mathrm{NH}_{4}^{+}-\mathrm{N}\right]_{\mathrm{in}}+\left[\mathrm{NO}_{2}^{-}-\mathrm{N}\right]_{\mathrm{in}}-\left[\mathrm{NH}_{4}^{+}-\mathrm{N}\right]_{\mathrm{ef}}-\left[\mathrm{NO}_{2}^{-}-\mathrm{N}\right]_{\mathrm{ef}}-\left[\mathrm{NO}_{3}^{-}-\mathrm{N}\right]\right)_{\text {ef }}}{\mathrm{WTH}}$

TPN $\left(\mathrm{kg}-\mathrm{N} / \mathrm{m}^{3} \cdot \mathrm{h}\right)=\frac{\left[\mathrm{NH}_{4}^{+}-\mathrm{N}\right]_{\text {in }}+\left[\mathrm{NO}_{2}^{-}-\mathrm{N}\right]_{\text {in }}}{\text { WTH }}$

Keterangan :

$\left[\mathrm{NH}_{4}^{+}-\mathrm{N}\right]_{\text {in }}=$ Konsentrasi influen ammonium

$\left[\mathrm{NO}_{2}^{-}-\mathrm{N}\right]_{\text {in }}=$ Konsentrasi influen nitrit

$\left[\mathrm{NH}_{4}^{+}-\mathrm{N}\right]_{\text {ef }} \quad=$ Konsentrasi efluen ammonium

$\left[\mathrm{NO}_{2}^{-}-\mathrm{N}\right]_{\text {ef }} \quad=$ Konsentrasi efluen nitrit

$\left[\mathrm{NO}_{3}^{-}-\mathrm{N}\right]_{\text {ef }} \quad=$ Konsentrasi efluen nitrat

EKA = Efisiensi konversi amonia

EPN = Efisiensi penyisihan nitrogen

TPyN = Tingkat penyisihan nitrogen

TPN= = Tingkat pemuatan nitrogen

WTH = Waktu tinggal hidrolik $(\mathrm{h})$

Reaktor dioperasikan selama 78 hari yang dibagi menjadi 2 periode dengan variasi WTH. Selama operasi, berlangsungnya proses anammox dapat di amati dengan perubahan konsentrasi nitrogen berdasarkan stoikiometri proses anammox, sebagaimana persamaan 5 .

$\mathrm{NH}_{4}^{+}+1.32 \mathrm{NO}_{2}^{-}+0.066 \mathrm{HCO}_{3}^{-}+0.13 \mathrm{H}^{+}=$ $1.02 \mathrm{~N}_{2}+0.26 \mathrm{NO}_{3}^{-}+0.066 \mathrm{CH}_{2} \mathrm{O}_{0.5} \mathrm{~N}_{0.15}+$ $2.03 \mathrm{H}_{2} \mathrm{O}$

\section{HASIL DAN PEMBAHASAN}

\subsection{Stoikiometri percobaan}

Reaksi anammox yang berlangsung secara anaerobik akan menghasilkan 0.26 mol nitrat dan 1,02 mol gas nitrogen yang merupakan indikator berlangsungnya proses anammox dari konversi $1 \mathrm{~mol}$ amonium direaksikan dengan 1,32 mol nitrit. Rasio konsentrasi $\mathrm{NH}_{4}{ }^{+}-\mathrm{N}$ dan $\mathrm{NO}_{2}^{-}-\mathrm{N}$ pada air limbah artifisial yang disuplai ke 
reaktor adalah 1. Nilai rasio rata-rata $\Delta \mathrm{NO}_{2}^{-}-$ $\mathrm{N}: \Delta \mathrm{NH}_{4}{ }^{+}-\mathrm{N}$ yang didapatkan dari percobaan berdasarkan Gambar 3 yaitu 1,20 dimana nilainya lebih kecil dari rasio stoikiometri anammox 1,32. Hal ini terjadi karena perbedaan kondisi operasional reaktor seperti jenis reaktor, spesies yang digunakan dan temperatur dalam pengoperasian. Strous et al. (1998) dalam penelitiannya menggunakan reaktor SBR dengan menggunakan biomassa bakteri anammox berbentuk granular pada suhu optimum $32-33^{\circ} \mathrm{C}^{(9)}$.

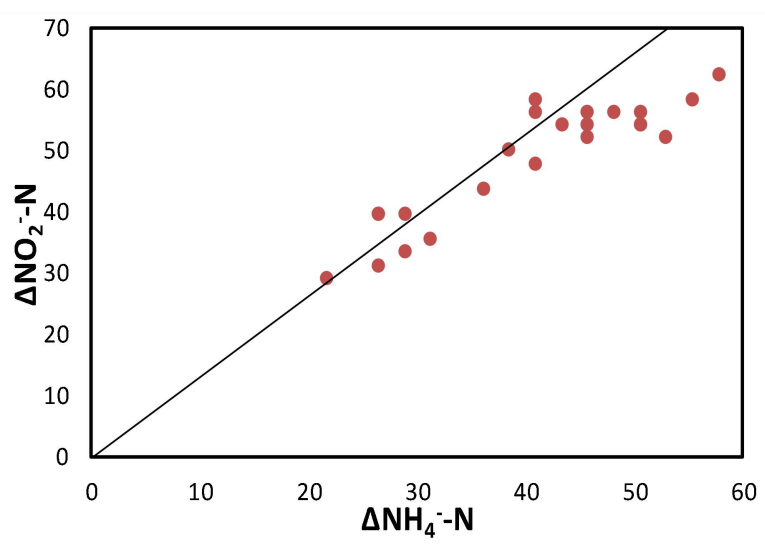

Gambar 3. Rasio $\Delta \mathrm{NO}_{2}-\mathrm{N} / \Delta \mathrm{NH}_{4}-\mathrm{N}$

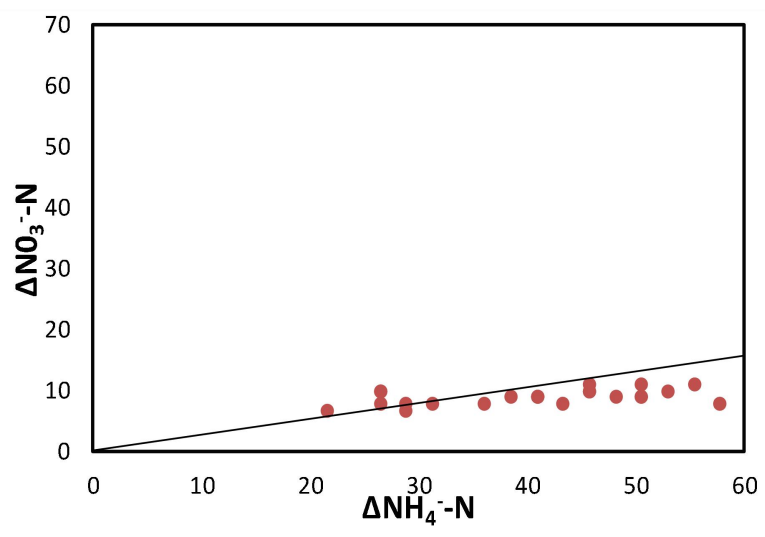

Gambar 4. Rasio $\Delta \mathrm{NO}_{3}-\mathrm{N} / \Delta \mathrm{NH}_{4}-\mathrm{N}$

Sedangkan Lotti et al. (2014) menggunakan reaktor MBR dengan biomasa bakteri anammox berbentuk biofilm pada suhu $30{ }^{\circ} \mathrm{C}$. Sedangkan rasio rata-rata $\Delta \mathrm{NO}_{3}{ }^{-}-$ $\mathrm{N}: \Delta \mathrm{NH}_{4}{ }^{+}-\mathrm{N}$ berdasarkan Gambar 4 yaitu 0,21 , lebih kecil dari rasio stoikiometri anammox yaitu 0,26 . Hal ini disebabkan oleh kemungkinan terjadinya proses denitrifikasi yang juga berlangsung pada reaktor, dimana dalam keadaan anaerobik bakteri denitrifikasi dapat merubah nitrat menjadi gas nitrogen dengan menggunakan karbon organik yang berasal dari biomasa bakteri anammox yang mati(10,11). Sehingga nitrat yang dihasilkan oleh proses anammox akan diubah menjadi gas nitrogen oleh bakteri denitrifikasi ${ }^{(12,13)}$. Berdasarkan rasio $\Delta \mathrm{NH}_{4}{ }^{+}-\mathrm{N}$ dan $\Delta \mathrm{NO}_{2}{ }^{-} \mathrm{N}$ dan adanya $\Delta \mathrm{NO}_{3}^{-}-\mathrm{N}$ yang dihasilkan, mengindikasikan bahwa proses anammox tetap berlangsung dalam kondisi dibawah suhu optimal.

\subsection{Profil nitrogen pada reaktor anammox UASB}

\subsubsection{Amonium}

Gambar 5 memperlihatkan profil nitrogen selama operasional reaktor anammox UASB yang menunjukkan perbandingan konsentrasi influen terhadap konsentrasi efluen. Berdasarkan Gambar 5, pada periode pertama dengan WTH 24 jam tingkat penyisihan amonium menurun secara bertahap dari 46,02 $\mathrm{mg}-\mathrm{N} / \mathrm{L}$ sampai $12,29 \mathrm{mg}-\mathrm{N} / \mathrm{L}$ pada akhir periode, efesiensi penyisihan amonium tertinggi terjadi pada hari ke 47 yaitu sebesar $82 \%$ sedangkan penyisihan terendah terjadi pada hari ke 2 pengukuran yaitu 32\%. Selanjutnya, pada periode kedua, WTH diturunkan menjadi 12 jam, sehingga TPN meningkat dari 0,14 kg$\mathrm{N} / \mathrm{m}^{3}$.h menjadi $0,28 \mathrm{~kg}-\mathrm{N} / \mathrm{m}^{3}$.h. Perubahan ini menyebabkan shock loading pada reaktor anammox, karena peningkatan pemuatan nitrogen yang tidak sebanding dengan pertumbuhan bakteri anammox yang lambat, waktu penggandaan maksimum 7 hari(14). Sehingga bakteri anammox membutuhkan waktu lebih lama untuk meningkatkan kembali kinerjanya. Hal ini terlihat pada hasil pengukuran pada periode kedua menunjukkan konsentrasi efluen amonium naik menjadi 29,16 $\mathrm{mg}-\mathrm{N} / \mathrm{L}$, selanjutnya konsentrasi efluen menurun secara bertahap hingga 19,52 mg-N/L.

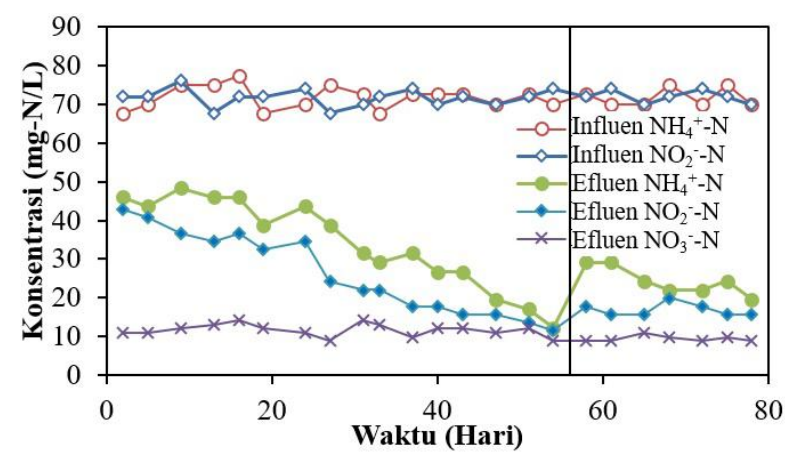

Gambar 5. Kinerja penyisihan nitrogen pada reaktor UASB.

\subsubsection{Nitrit}

Sebagaimana amonium, nitrit juga merupakan makanan bagi bakteri anammox, yang merupakan penerima elektron untuk 
merubah amonium menjadi gas nitrogen dalam kondisi anaerobik. Sehingga penurunan konsentrasi amonia sebanding dengan nitrit berdasarkan rasio stoikiometeri proses anammox. Dapat dilihat pada Gambar 5, bahwa pada periode I dengan WTH 24 jam, konsentrasi nitrit pada efluen menurun secara bertahap dari $42,83 \mathrm{mg}-\mathrm{N} / \mathrm{L}$ ke 11,64 mg-N/L. Hal ini membuktikan bahwa nitrit yang hilang digunakan oleh bakteri anammox bersama dengan amonium menjadi gas nitrogen. Dilihat dari persentase penyisihan nitrit, hasil tertinggi terjadi pada hari ke 54 yaitu 84\% sedangkan penyisihan terendah terjadi pada hari pertama pengukuran yaitu $40 \%$. Granular biakan yang digunakan merupakan bakteri anammox yang sudah dikultivasi, maka proses penyisihan nitrogen dapat berlangsung sejak pertama operasional, hal ini akan berbeda, jika lumpur biakan (seeding slude) berasal dari lingkungan. Berdasarkan pengalaman pertama operasional reaktor anammox dengan biakan lumpur nitrifikasi, membutuhkan waktu 3 tahun untuk menghasilkan kinerja yang tinggi. Maka untuk mempercepat start-up reaktor anammox, penggunaan biomasa anammox secara langsung merupakan rekomendasi yang tepat untuk mendapatkan kinerja penyisihan nitrogen yang diinginkan ${ }^{(15)}$.

Pada periode II, WTH diturunkan menjadi 12 jam, yang berakibat terganggunya proses anammox karena peningkatan TPN menjadi dua kali lipat sehingga bakteri anammox mengalami shock loading. Selain itu, nitrit yang merupakan substrat bagi bakteri anammox, juga dapat menjadi inhibitor proses anammox. Walaupun, konsentrasi nitrit yang menyebabkan inhibisi sangat bervariasi. Seperti Reaktor DEMON ${ }^{\circledR}$ yang menjaga agar konsentrasi nitrit dibawah 5 $\mathrm{mg} / \mathrm{L}$, karena pada konsentrasi $>10 \mathrm{mg} / \mathrm{L}$ terjadi inhibisi. Strous et al. (1999) melaporkan terjadinya inhibisi total pada konsentrasi nitrit 100 g-N/L, begitu juga Dapena-Mora et al. (2007) mendapatkan angka yang lebih tinggi yaitu 50\% inhibisi terjadi pada konsentasi nitrit $350 \mathrm{mg}-$ $\mathrm{N} / \mathrm{L}^{(16,17)}$. Peningkatan konsentrasi nitrit pada efluen menjadi $17,88 \mathrm{mg}-\mathrm{N} / \mathrm{L}$ dan nilai ini relatif stabil hingga akhir periode kedua dengan konsentrasi nitrit menurun kembali hingga 15,80 $\mathrm{mg}-\mathrm{N} / \mathrm{L}$.

\subsubsection{Nitrat}

Konsentrasi nitrat pada efluen yang terukur dari awal hingga akhir yaitu berkisar dari 8,79 mg-N/L hingga 14,21 mg-N/L. Keberadaan nitrat di effluen membuktikan bahwa nitrat yang terbentuk merupakan hasil dari proses anammox yang berlangsung dalam kondisi anaerobik, sesuai dengan stoikiometri proses anammox dimana proses anammox menghasilkan nitrat.

\subsection{Kinerja Reaktor dan Efesiensi Penyisihan Nitrogen}

\subsubsection{TPN dan TPyN}

Kinerja penyisihan nitrogen dari reaktor UASB anammox berlangsung selama 68 hari dengan 2 periode waktu yaitu WTH 24 jam dan 12 jam. Nilai TPN diatur pada konsentrasi 0,14 $\mathrm{kg}-\mathrm{N} / \mathrm{m}^{3}$.h saat WTH 24 jam dan $0,28 \mathrm{~kg}-\mathrm{N} / \mathrm{m}^{3} . \mathrm{h}$ saat WTH 12 jam. Grafik penyisihan TPyN dan nilai TPN dapat dilihat pada Gambar 6. Hasil penelitian menunjukkan pada periode I (24 jam) nilai TPyN meningkat secara bertahap dari $0,044 \mathrm{~kg}-\mathrm{N} / \mathrm{m}^{3}$.h ke $0,113 \mathrm{~kg}-\mathrm{N} / \mathrm{m}^{3}$.h. Nilai TPyN maksimun terjadi pada hari ke 54 yaitu sebesar $0,113 \mathrm{~kg}-\mathrm{N} / \mathrm{m}^{3} . \mathrm{h}$ pada TPN $0,14 \mathrm{~kg}-\mathrm{N} / \mathrm{m}^{3} . \mathrm{h}$ Pada periode kedua, TPN meningkat menjadi $0,28 \mathrm{~kg}-\mathrm{N} / \mathrm{m}^{3} \cdot \mathrm{h}$ pada saat WTH diturunkan menjadi 12 jam. Sehingga TpyN juga meningkat, karena bakteri anammox memiliki kemampuan yang tinggi dalam penyisihan nitrogen. Bakteri anammox biasa digunakan untuk pengolahan air limbah dengan konsentrasi nitrogen yang tinggi. Walapun pada Gambar 5 terlihat bahwa konsentrasi amonium dan nitrit meningkat pada efluen, akan tetapi Nilai TPyN meningkat tajam dari $0,113 \mathrm{~kg}-\mathrm{N} / \mathrm{m}^{3} . \mathrm{h}$ menjadi $0,18 \mathrm{~kg}-\mathrm{N} / \mathrm{m}^{3} \cdot \mathrm{h}$ dengan kenaikan TPN. Selanjutnya TPyN berjalan konstran dan meningkat secara bertahap hingga $0,196 \mathrm{~kg}-\mathrm{N} / \mathrm{m}^{3} . \mathrm{h}$ pada TPN $0,28 \mathrm{~kg}-\mathrm{N} / \mathrm{m}^{3} . \mathrm{h}$.

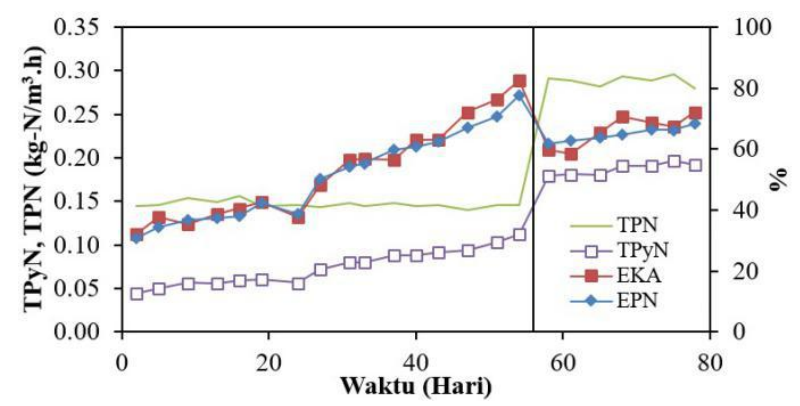

Gambar 6. Grafik tingkat dan efisiensi penyisihan nitrogen pada variasi WTH

Melihat kecendrungan peningkatan penyisihan nitrogen pada penelitian ini, TPN bisa diturunkan untuk mendapatkan waktu tinggal yang lebih singkat dengan tingkat penyisihan nitrogen yang tinggi. Sebagaimana halnya penelitian yang dilakukan oleh Hendrickx et al. (2012) menggunakan gas lift reactor pada suhu $20{ }^{\circ} \mathrm{C}$ didapatkan WTH 5,3 jam untuk pengolahan limbah domestik artifisial $^{(5)}$. Selain 
itu, kinerja penyisihan nitrogen dapat ditingkatkan dengan jumlah biomasa anammox yang besar, seperti yang dilaporkan oleh Ma et al. 2013, menggunakan reator UASB volume $8 \mathrm{~L}$ yang penuh dengan flok biomasa anammox. Sehingga penyisihan nitrogen sangat tinggi, TPyN mencapai $5,72 \mathrm{~kg}-\mathrm{N} / \mathrm{m}^{3} . \mathrm{h}$ pada suhu 30 ${ }^{\circ} \mathrm{C}$ dengan WTH 0,12 jam dan menurun menjadi $2,28 \mathrm{~kg}-\mathrm{N} / \mathrm{m}^{3}$.h pada suhu $16^{\circ} \mathrm{C}$ dengan WTH 0,28 jam $^{(6)}$.

Kinerja penyisihan nitrogen dapat terus ditingkatkan sebanding dengan waktu operasional reaktor dengan meningkatkan konsentrasi ammonium dan nitrit pada limbah artifisial dan mengurangi WTH sebagaimana yang dilaporkan oleh Agustina et al. (2017), dimana nilai TPyN mencapai $1.05 \mathrm{~kg}-\mathrm{N} / \mathrm{m}^{3} . \mathrm{h}$ dengan WTH 6 jam pada waktu operasional 178 hari dan suhu $25-27^{\circ} \mathrm{C}^{(18)}$.

\subsubsection{Efisiensi konversi amonia dan efisiensi penyisihan nitrogen}

Selama periode operasional reaktor sebagian besar amonium dan nitrit menghilang dan konsentrasi nitrat meningkat. Hal ini menunjukkan proses anammox berjalan dengan stabil selama masa percobaan. Hal ini ditunjukkan oleh grafik efisiensi penyisihan amonium (EPA) dan juga efesiensi penyisihan nitrogen (EPN).

Hasil penelitian menunjukkan pada periode I dengan WTH 24 jam EPA meningkat secara bertahap dari $32 \%$ hingga $82 \%$. Namun EKA turun menjadi $60 \%$ pada saat WTH diturunkan menjadi 12 jam. Selanjutnya EKA meningkat secara bertahap hingga $72 \%$. Sedangkan nilai EPN meningkat secara bertahap seiring dengan bertambahnya waktu pengoperasian. EPN diawal pengoperasian yaitu $31 \%$, terus meningkat hingga $77 \%$. Sama halnya dengan EKA efesiensi penyisihan nitrogen menurun pada WTH 12 jam hingga $61 \%$, selanjutnya konsentrasi EPN meningkat menjadi $68 \%$. Kinerja penyisihan proses anammox pada suhu tropis menggunakan reaktor UASB dengan biomassa bakteri anammox berbentuk granular memperlihatkan hasil yang sama dengan yang dilaporkan oleh Zulkarnaini et al. (2019) dimana nilai EKA dan EPN sebesar $72 \%$ dan $69 \%$ pada
WTH 12 jam dengan reaktor biofilm UASB menggunakan ijuk sebagai media lekat(19).

\subsection{Suhu dan pH}

Temperatur mempengaruhi aktifitas dan kelimpahan bakteri anammox. Fisiologi bakteri anammox genus Candidatus Brocadia menunjukkan bahwa pertumbuhan optimumnya pada suhu $30-40{ }^{\circ} \mathrm{C}^{(20,21)}$. Pada suhu yang lebih tinggi dari $45^{\circ} \mathrm{C}$, terjadi penurunan aktifitas anammox yang bersifat tidak balik (irreversible) karena terjadinya lisis sel biomasa anammox ${ }^{(22)}$. Pada penelitian kali ini proses anammox dilakukan pada suhu ambient (skala laboratorium). Suhu yang terukur selama pengambilan sampel yaitu dari $23-28^{\circ} \mathrm{C}$. Berdasarkan penelitian yang telah dilakukan, bakteri anammox mampu tumbuh dan dapat menyesuaikan diri pada daerah dengan suhu dibawah kondisi optimum, terbukti dengan adanya penyisihan nitrogen yang terjadi selama masa percobaan. Penelitian yang dilakukan Isaka et al. (2007) melaporkan bahwa TPyN $11,5 \mathrm{~kg}-\mathrm{N} / \mathrm{m}^{3} . \mathrm{h}$ dicapai pada $37^{\circ} \mathrm{C}$, sedangkan nilai TPyN turun menjadi $8,1 \mathrm{~kg}-\mathrm{N} / \mathrm{m}^{3} . \mathrm{h}$ pada suhu sedang $20-22^{\circ} \mathrm{C}^{(23)}$. Dosta et al. (2008) melaporkan bahwa sistem anammox dapat berhasil dioperasikan pada $18^{\circ} \mathrm{C}$, namun nitrit mulai menumpuk dan stabilitasnya hilang pada suhu $15{ }^{\circ} \mathrm{C}^{(22)}$. Penelitian terkait menunjukkan bahwa bakteri anammox dapat menyesuaikan diri dengan kondisi suhu rendah melalui proses

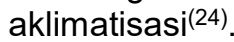

Bakteri anammox dapat tumbuh dengan baik pada $\mathrm{pH}$ optimum $6,7-8,3^{(4)}$. Dalam aliran kontinu sistem lumpur granular anammox yang berada pada $\mathrm{pH}$ efluen 8,5-9,3, reaksi anammox masih berjalan dengan stabil. Dari percobaan didapatkan nilai $\mathrm{pH}$ dalam rentang $7,2-8,1$, hal ini membuktikan selama percobaan nilai $\mathrm{pH}$ berada pada kondisi optimum. Sehingga tidak terjadi inhibisi selama operasional reaktor walaupun $\mathrm{pH}$ reaktor tidak dikontrol (tanpa penambahan asam atau basa). Tabel 2 memperlihatkan perbandingan penelitian tentang anammox dengan berbagai tipe reaktor, variasi suhu operasional dan jenis biomassa anammox.

Tabel 1. Kondisi operasional reaktor anammox

\begin{tabular}{ccccc}
\hline Periode & Hari & \multicolumn{2}{c}{ Konsentrasi (mg-N/L) } & WTH \\
\cline { 3 - 5 } & & $\mathbf{N H}^{+}-\mathbf{N}$ & $\mathbf{N O}_{2}{ }^{-}-\mathbf{N}$ & \\
(jam) & 70 & 24 \\
II & $1-56$ & 70 & 70 & 12 \\
\hline
\end{tabular}


Tabel 2. Kinerja berbagai tipe reaktor anammox

\begin{tabular}{|c|c|c|c|c|c|c|c|c|}
\hline No. & Reaktor & Media & $\begin{array}{c}\text { Waktu } \\
\text { Penelitian } \\
\text { (Hari) }\end{array}$ & $\begin{array}{c}\text { HRT } \\
\text { (Jam) }\end{array}$ & $\begin{array}{l}\text { Suhu } \\
\left({ }^{\circ} \mathrm{C}\right)\end{array}$ & Limbah & $\begin{array}{l}\text { Kinerja } \\
\text { Proses }\end{array}$ & Referensi \\
\hline 1 & UASB & $\begin{array}{l}\text { Spons } \\
\text { Hitam }\end{array}$ & 200 & 0,12 & $\begin{array}{l}16- \\
30\end{array}$ & $\begin{array}{l}\text { Air } \\
\text { Buangan }\end{array}$ & $\begin{array}{l}\text { TPN: } 1.14 \text { dan12 } \mathrm{kg}-\mathrm{N} / \mathrm{m}^{3} \cdot \mathrm{d} \\
\text { TPyN: } 5,72 \mathrm{~kg}-\mathrm{N} / \mathrm{m}^{3} \cdot \mathrm{d} \\
\text { EPN: } 94 \%\end{array}$ & (6) \\
\hline 2 & UASB & Granular & 450 & 0,50 & 35 & Artifisial & $\begin{array}{l}\text { TPN: } 89,1 \mathrm{~kg}-\mathrm{N} / \mathrm{m}^{3} \cdot \mathrm{d} \\
\text { TPyN: } 74,3-76,7 \mathrm{~kg}-\mathrm{N} / \mathrm{m}^{3} . \mathrm{d} \\
\text { EPN: } 90 \%\end{array}$ & (26) \\
\hline 3 & UMABR & Membran & 200 & $16-32$ & 25 & Artifisial & $\begin{array}{l}\text { TPN: } 0,104 \mathrm{~kg}-\mathrm{N} / \mathrm{m}^{3} \cdot \mathrm{d} \\
\text { TPyN: } 0,07 \mathrm{~kg}-\mathrm{N} / \mathrm{m}^{3} \cdot \mathrm{d} \\
\text { EPN: } 89 \%\end{array}$ & (27) \\
\hline 4 & UASB & ljuk & 78 & $\begin{array}{l}12 \\
\text { dan } \\
24\end{array}$ & $\begin{array}{l}25- \\
28\end{array}$ & Artifisial & $\begin{array}{l}\text { TPN: } 0,14 \text { dan } 0,28 \mathrm{~kg}-\mathrm{N} / \mathrm{m}^{3} \cdot \mathrm{d} \\
\text { TPyN: } 0,200 \mathrm{~kg}-\mathrm{N} / \mathrm{m}^{3} \cdot \mathrm{d} \\
\text { EPN: } 76 \% \\
\text { EPA: } 79 \%\end{array}$ & (19) \\
\hline 5 & UASB & $\begin{array}{l}\text { poliester } \\
\text { non- } \\
\text { woven } \\
\text { berpori }\end{array}$ & 185 & $24-6$ & $\begin{array}{l}25- \\
27\end{array}$ & Artifisial & $\begin{array}{l}\text { TPN: } 0,35-1,20 \mathrm{~kg}-\mathrm{N} / \mathrm{m}^{3} \cdot \mathrm{d} \\
\text { TPyN: } 1,05 \mathrm{~kg}-\mathrm{N} / \mathrm{m}^{3} \cdot \mathrm{d} \\
\text { EPN: } 74 \%\end{array}$ & (18) \\
\hline 6 & UASB & Granular & 78 & $\begin{array}{l}12 \\
\text { dan } \\
24\end{array}$ & $\begin{array}{l}23- \\
28\end{array}$ & Artifisial & $\begin{array}{l}\text { TPN: } 0,14 \text { dan } 0,28 \mathrm{~kg}-\mathrm{N} / \mathrm{m}^{3} \cdot \mathrm{d} \\
\text { TPyN: } 0,196 \mathrm{~kg}-\mathrm{N} / \mathrm{m}^{3} \cdot \mathrm{d} \\
\text { EPN: } 77 \% \\
\text { EPA: } 82 \%\end{array}$ & $\begin{array}{l}\text { Penelitian } \\
\text { ini }\end{array}$ \\
\hline
\end{tabular}

\subsection{Konsentrasi FA dan FNA}

Jaroszynski et al. (2011) melaporkan bahwa reaktor dapat dioperasikan pada tingkat amonium dan nitrit yang lebih tinggi dengan $\mathrm{pH}$ yang lebih rendah(25). $\mathrm{pH}$ rendah dapat menurunkan konsentrasi Free Ammonia (FA) tetapi meningkatkan konsentrasi Free Nitrous Acid (FNA), sedangkan $\mathrm{pH}$ tinggi dapat meningkatkan konsentrasi FA tetapi menurunkan konsentrasi FNA. Pada konsentrasi FA $29,65 \mathrm{mg} / \mathrm{L}$ dapat menghambat proses anammox, sedangkan FNA (Free Nitrous Acid) dapat menyebabkan penghambatan proses anammox pada konsentrasi $77,02 \mu \mathrm{g} / \mathrm{L}$.

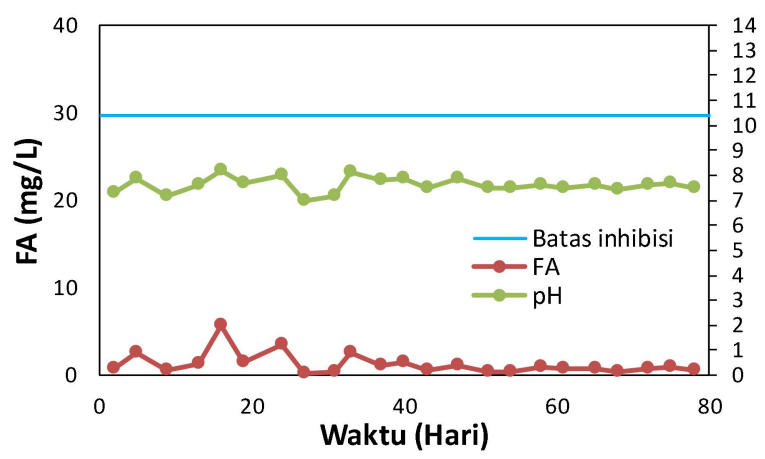

Gambar 7. Grafik Konsentrasi FA dan pH

Konsentrasi FA dari awal sampai akhir penelitian berkisar dari 0,3-5,6 mg-N/L. Konsentrasi tertinggi terjadi pada hari ke 16 sedangkan terendah pada hari ke 31. Sedangkan konsentrasi FNA yang didapat berkisar dari 0,001-0,015 mg-N/L. Konsentrasi tertinggi terjadi pada hari ke 9 dan terendah pada hari ke 33. Konsentrasi FA dan FNA selama pengukuran didapatkan lebih rendah dari ambang batas inhibisi, hal ini mengindikasikan bahwa proses anammox terbebas dari faktor penghambat. Grafik konsentrasi FA dan FNA dapat dilihat pada Gambar 7 dan Gambar 8.

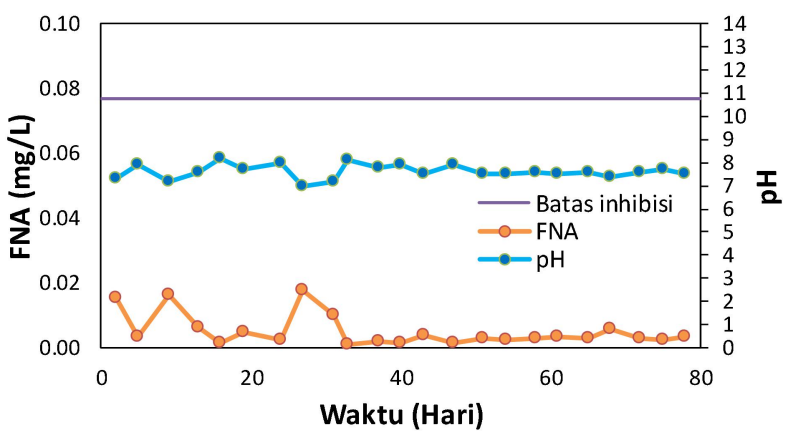

Gambar 8. Grafik Konsentrasi FNA dan pH

\section{KESIMPULAN}

Berdasarkan hasil penelitian mengenai penyisihan nitrogen menggunakan proses anammox menggunakan Up-Flow Anaerobic Sludge Blanket (UASB) reaktor, maka dapat disimpulkan nilai rasio $\Delta \mathrm{NH}_{4}-\mathrm{N}: \Delta \mathrm{NO}_{2}-\mathrm{N}$ dan $\Delta \mathrm{NO}_{3}: \Delta \mathrm{NH}_{4}$ didapatkan sebesar 1,20 dan 0,21 , mendekati rasio stoikiometri anammox. Kinerja penyisihan nitrogen selama penelitian pada WTH 24 jam dan TPN $0,14 \quad \mathrm{~kg}-\mathrm{N} / \mathrm{m}^{3} . \mathrm{h}$ didapatkan nilai TPyN optimum $0,113 \mathrm{~kg}$ $\mathrm{N} / \mathrm{m}^{3}$.h, pada WTH 12 jam dan TPN $0,28 \mathrm{~kg}$ $\mathrm{N} / \mathrm{m}^{3}$.h nilai TPyN meningkat sampai $0,196 \mathrm{~kg}-$ $\mathrm{N} / \mathrm{m}^{3}$.h. Efesiensi penyisihan EKA dan EPN pada WTH 24 jam mencapai $82 \%$ dan $77 \%$, pada saat penurunan WTH menjadi 12 jam 
efesiensi EKA dan EPN menjadi $72 \%$ dan $68 \%$. Proses anammox dapat berlangsung stabil pada daerah dengan suhu tropis.

\section{PERSANTUNAN}

Ucapan terima kasih disampaikan kepada Kementerian Riset, Teknologi, dan Pendidikan Tinggi Republik Indonesia yang telah memberikan dukungan kerjasama dan pendanaan dalam penelitian ini. Penelitian ini dibiayai oleh Kementerian Riset, Teknologi, dan Pendidikan Tinggi Republik Indonesia dengan nomor kontrak No. 051/SP2H/LT/DRPM/2019.

\section{DAFTAR PUSTAKA}

1. Kartal, B., Almeida, NM. De., Maalcke, W.J., Camp HJMO Den, Jetten MSM, Keltjens JT. (2013). How to make a living from anaerobic ammonium oxidation. FEMS Microbiol Rev. 37(3):428-461. doi:10.1111/1574-6976.12014

2. Ali, M., Okabe, S. (2015). Anammox-based technologies for nitrogen removal: Advances in process start-up and remaining issues. Chemosphere. 141:144-153. doi:10.1016/j.chemosphere.2015.06.094

3. Lackner, S., Gilbert, E.M., Vlaeminck, S.E., Joss A, Horn H, van Loosdrecht MCM. (2014). Full-scale partial nitritation/anammox experiences - An application survey. Water Res. 55(0):292-303. doi:10.1016/j.watres.2014.02.032

4. Strous, M., Gijs Kuenen, J., Jetten, M.S.M. (1999). Key Physiology of Anaerobic Ammonium Oxidation Downloaded from. Appl Environ Microbiol. 65(7):3248-3250. doi:papers2://publication/uuid/E9A1573A6D62-420E-94D0-CA7C84D0FEB9

5. Hendrickx, T.L.G., Wang, Y., Kampman, C., Zeeman, G., Temmink, H., Buisman, C.J.N. (2012). Autotrophic nitrogen removal from low strength waste water at low temperature. Water Res. 46(7):2187-2193. doi:10.1016/j.watres.2012.01.037

6. Ma, B., Peng, Y., Zhang, S., Wang, J., Gan, Y., Chang, J., Wang, S., Wang, S., Zhu, G. (2013). Performance of anammox UASB reactor treating low strength wastewater under moderate and low temperatures. Bioresour Technol. 129:606-611. doi:10.1016/j.biortech.2012.11.025

7. Kumar, M., Daverey, A., Gu, J.D., Lin, J.G. (2016). Anammox Processes. doi:10.1016/B978-0-444-63665-2.00015-1

8. Van De Graaf, A.A., De Bruijn, P., Robertson, L.A., Jetten M.S.M.M., Kuenen, J.G. (1996).
Autotrophic growth of anaerobic ammoniumoxidizing micro-organisms in a fluidized bed reactor. Microbiology. 142(8):2187-2196. doi:10.1099/13500872-142-8-2187

9. Strous, M., Heijnen, J. J., Kuenen, J. G., \& Jetten, M. S. M. (1998). The sequencing batch reactor as a powerful tool for the study of slowly growing anaerobic ammoniumoxidizing microorganisms. Appl Microbiol Biotechnol. doi:10.1007/s002530051340 50(5):589-596.

10.Lotti, T., Kleerebezem, R., Lubello, C., van Loosdrecht, M.C.M.M. (2014). Physiological and kinetic characterization of a suspended cell anammox culture. Water Res. 60:1-14. doi:10.1016/j.watres.2014.04.017

11. Kindaichi, T., Yuri, S., Ozaki, N., Ohashi, A. (2012). Ecophysiological role and function of uncultured Chloroflexi in an anammox reactor. 66(October):2561. doi:10.2166/wst.2012.479

12.Winkler, M.K.H., Yang, J., Kleerebezem, R., Plaza, E., Trela, J., Hultman, B., Van Loosdrecht, M.C. (2012). Nitrate reduction by organotrophic Anammox bacteria in a nitritation/anammox granular sludge and a moving bed biofilm reactor. Bioresour Technol. 114:217-223. doi:10.1016/j.biortech.2012.03.070

13.Du, R., Cao, S., Wang, S., Niu, M., Peng, Y. (2016). Performance of partial denitrification (PD)-ANAMMOX process in simultaneously treating nitrate and low $\mathrm{C} / \mathrm{N}$ domestic wastewater at low temperature. Bioresour Technol. 219(3):420-429. doi:10.1016/j.biortech.2016.07.101

14. Oshiki, M., Shimokawa, M., Fujii, N., Satoh, H., Okabe, S. (2011). Physiological characteristics of the anaerobic ammoniumoxidizing bacterium "Candidatus Brocadia sinica." Microbiology. 157(6):1706-1713. doi:10.1099/mic.0.048595-0

15. Van der Star, W.R.L.L., Abma, W.R., Blommers, D., Blommers, D., dan Mulder, J.W (2007). Startup of reactors for anoxic ammonium oxidation: Experiences from the first full-scale anammox reactor in Rotterdam. Water Res. 41(18):4149-4163. doi:10.1016/j.watres.2007.03.044

16.Strous, M., Kuenen, J.G., Jetten, M.S.M. (1999). Key Physiology of Anaerobic Ammonium Oxidation Key Physiology of Anaerobic Ammonium Oxidation. Appl Environ $\quad$ Microbiol. 65(7):0-3. doi:papers2://publication/uuid/E9A1573A6D62-420E-94D0-CA7C84D0FEB9 
17. Dapena-Mora, A., Fernández, I., Campos, J.L., Mosquera-Corral, A., Mendez, R.R., dan Jetten, M.S.M. (2007). Evaluation of activity and inhibition effects on Anammox process by batch tests based on the nitrogen gas production. Enzyme Microb Technol. 40(4):859-865.

doi:10.1016/j.enzmictec.2006.06.018

18. Agustina, T.E., Novia, N., Diansyah, G., Ike, M., dan Soda, S. (2017). Nitrogen Removal by Anammox Biofilm Column Reactor at Moderately Low Temperature. Indones $J$ Fundam Appl Chem. 2(3):78-82. doi:10.24845/ijfac.v2.i4.78

19. Zulkarnaini, Nur, A., dan Ermaliza, W. (2019). Nitrogen Removal in the Anammox Biofilm Reactor using Palm Fiber as Carrier in Tropical Temperature Operation. Jurnal Riset Teknologi Pencegahan Pencemaran Industri. 10(2):7-15.

20. Oshiki, M., Shimokawa, M, Fujii, N., Satoh, H., dan Okabe, S. (2011). Physiological characteristics of the anaerobic ammoniumoxidizing bacterium ' Candidatus Brocadia sinica $\quad$ 1706-1713. doi:10.1099/mic.0.048595-0

21.Egli, K., Fanger, U., Alvarez, P.J.J., Siegrist, H., Van der Meer, J.R., dan Zehnder, A.J.B. (2001). Enrichment and characterization of an anammox bacterium from a rotating biological contactor treating ammonium-rich leachate. Arch Microbiol. 175(3):198-207. doi:10.1007/s002030100255
22. Dosta, J., Fernandez, I., Vazquez-Padin J, et al. (2008). Short- and long-term effects of temperature on the ANAMMOX process. J Hazard Mater. 154:688-693. doi:10.1016/j.jhazmat.2007.10.082

23. Isaka, K., Sumino, T., dan Tsuneda, S. (2007) High nitrogen removal performance at moderately low temperature utilizing anaerobic ammonium oxidation reactions. $J$ Biosci Bioeng. 103(5):486-490. doi:10.1263/jbb.103.486

24. Lotti, T., Kleerebezem, R., van Loosdrecht, M.C.M. (2015). Effect of temperature change on anammox activity. Biotechnol Bioeng. 112(1):98-103. doi:10.1002/bit.25333

25. Jaroszynski, L.W., Cicek, N., Sparling, R., dan Oleszkiewicz, J.A. (2011). Bioresource Technology Importance of the operating $\mathrm{pH}$ in maintaining the stability of anoxic ammonium oxidation ( anammox ) activity in moving bed biofilm reactors. Bioresour Technol. 102(14):7051-7056. doi:10.1016/j.biortech.2011.04.069

26.Tang, C. J., Zheng, P, Wang, C.H, Mahmood, Q., Zhang, J.Q., Cheng, X.G, Zhang, L., dan Chen, J.W. (2010). Performance of highloaded ANAMMOX UASB reactors containing granular sludge. Water Res. 45(1):135-144. doi:10.1016/j.watres.2010.08.018

27.Li, X., Sun, S., Badgley, B.D., Sung, S., Zhang H, He Z. (2016). Nitrogen removal by granular nitritation-anammox in an upflow membrane-aerated biofilm reactor. Water Res. 94:23-31. doi:10.1016/j.watres.2016.02.031 